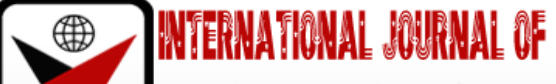

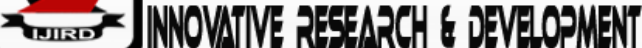

ISSN 2278-0211 (Online)

\section{Genetic Variability and Heritability of Growth and Yield Characters of Cowpea Germplasm under Gaya Sudan Savannah}

\author{
Professor, Department of Crop Science, Kano University of Science and Technology, Nigeria \\ Shawai R. S \\ Research Scholar, Department of Crop Science, Kano University of Science and Technology, Nigeria \\ Muhammad A \\ Research Scholar, Department of Crop Science, Kano University of Science and Technology, Nigeria \\ Tijjani S. S \\ PG Student, Department of Crop Science, Kano University of Science and Technology, Nigeria
}

\begin{abstract}
:
Field experiment was conducted at Teaching and Research Farm of Kano University of Science and Technology, Wudil located at Gaya Sudan Savannah agro ecological zone of Nigeria to determine the genetic variability and heritability of some quantitative characters of different Cowpea Germplasm. Five (5) Cowpea cultivars were sown in a randomized complete block design (RCBD) with 3 replications.Number of days to germination, days to branching, days to 50\% flowering, days to pod setting, number of pods per plant, number of seeds per pod and 100 seeds weight were determined and recorded as growth and yield parameters. The result showed a high significant variability for all the tested traits except days to flowering and days to branching. All the PCV values were higher than the GCV values for each character and showed similar pattern of changing over the characters. The highest heritability was recorded in favor of hundred seeds weight. Based on the results obtained above it is concluded that Genotypic variation can be used for effective selection based on phenotypic expression and heritability value of a trait.
\end{abstract}

Keywords: Cowpea, genetic variability, heritability, phenotype

\section{Introduction}

Cowpea is a dicotyledonous plant belonging to the family fabaceae and sub-family fabiodae. Cowpea (Vignaunguilata (L.) Walp) is cultivated under diverse soil and climatic conditions in Africa. Cowpea is adapted to warm weather and requires less rainfall than most crops, therefore, it is cultivated in the semi-arid and arid regions of low land and sub tropics, where soils are poor and rainfall is limited [1]

World production of cowpea has been estimated to be 2.27 millions tons of which Nigeria produce about 850,000 tones [2],[3].Egho(2009)reported that Nigeria is the second greatest consumer of cowpea in the whole world [4]. Among the legumes, cowpea is the most extensively grown, distributed and traded food crop, accounting for more than 50\% [5] .This is because the crop is of considerable nutritional and health value to man and livestock [5].

Cowpea is of major importance to the livelihoods of millions of relatively poor people in less developed countries of the tropics [2]. Islam et al. [6] emphasized that all parts of the plant used as food are nutritious providing protein and vitamins, immature pods and peas are used as vegetables while several snack and main dishes are prepared from the grains [7]. They also form a major staple in the diets of Africa and Asian continents. Agbogidi regarded cowpea as the poor man's source of proteins [5]. Their amino acid complements those of cereals [4]. Their minerals contents; calcium and Iron are higher than that of meat, fish and egg and the Iron content equates that of milk; the vitamins-thiamin, riboflavin, niacin (water soluble) and their levels compared with that found in lean meat and fish [9] Cowpea is a cheap source of protein (20-26\%) and starch (50-67\%) [10]. The leaves, stems and seeds have antimicrobial properties that frequent consumers had lower blood pressures (BP) and total serum cholesterol levels. Consequently, consumers will be less likely to be diagnosed with high BP, diabetes and other heart diseases.

Besides its nutritional and health related benefits, beans are inexpensive, considerably cheaper than rice or any other dietary fibre. It is a good food security item as it mixes with other recipe [11], [12].

In Nigeria, the varieties under cultivation are unimproved, local types which are photoperiod sensitive when planted in the normal planting (rainy) season (June-July) coincides with long days. When planted in the dry season with irrigation they mature within 60-80 days but remain stunted in growth under low temperature conditions (Mukhtar and Singh, 2006) resulting in poor fodder vields.A significant number of cowpea varieties are under cultivation in some part of Nigeria. 
Africa and globe, however not all of them found the suitable condition to give maximum yield due to some environmental condition and genetic attributes militating its production.It is therefore clear that sustainable increases in agricultural productivity and rural incomes are the basis for broad-based economic growth [13]. Therefore this study is designed to evaluate the variability and heritability ofgrowth and yield characters of cowpea germplasm under Gaya condition.

\section{Materials and Methods}

\subsection{Study Site}

The research was conducted at the University Research Farm, Kano University of Science and Technology Wudil, Kano State located at Gaya ( $11^{0} 58^{\prime} \mathrm{N}$ and $\left.8^{0} 25 \mathrm{E}\right)$ in the Sudan Savannah ecological zone of Nigeria[16].The area is characterized by two seasons: the rainy season with long day length, usually begins from May and ends in September with heavier rain falls in July and August. The dry season is characterized by short day length which begins in October and ends in April/May [17]. Total mean annual rainfall was $756 \mathrm{~mm}$, while the average minimum and maximum temperatures were $22^{\circ} \mathrm{C}$ and $34.8^{\circ} \mathrm{C}$, respectively. The minimum and maximum relative humidity was 33.1 and $56.0 \%$, respectively. The soils in the area formed on physiographic surfaces ranging from the 427 to $488 \mathrm{~m}$ above sea levels.

\subsection{Treatments and Experimental Design}

The experiment consists of five different cowpea germplasm; collected from the northern part of the country. The experiment was laid out in a Randomized Complete Block Design and replicated three times.The land was cleared out of debris, doubled harrowed and made to a fine filth later ridged of $0.75 \mathrm{~m}$ apart and the seeds was sown $5 \mathrm{~cm}$ depth using 75 by $25 \mathrm{~cm}$ both inter and intra row spacing after rains were established, three seeds were carefully placed per hole with a seed rate of $20-40 \mathrm{~kg} / \mathrm{ha}$. Seeds were treated with Apron plus at the rate of $10 \mathrm{~g} / 3 \mathrm{~kg}$ of seed before sowing. Fertilizer was applied as per treatment basis using N.P.K. (15:15:15) at 2 WAS by side placement method. All other agronomic practices were done on time to achieve good crop stand.

\subsection{Data Collection}

At developing and maturity stage a number of data were collected for the following parameters that includes number of days to germination, days to branching, days to $50 \%$ flowering, days to pod setting, number of pods per plants, number of seeds per pot and 100 seed weight.

\subsubsection{Number of Days to Germination}

The number of days to germination was recorded by counting the number of days from sowing up to the time of seedling emergence/germination was more than $70 \%$.

\subsection{Days to Branching}

This was recorded immediately after germination to the subsequent branching of plant.

\subsubsection{Days to $50 \%$ Flowering}

This was recorded by counting the number of days from sowing up to the time when over half of plant began to flower.

\subsubsection{Days to Pod Setting}

This was recorded by counting the number of days from flowering up to pod set by the plants

\subsubsection{Number of Pod per Plant}

This was determined by counting number of pods from selected five plants.

\subsubsection{Number of Seed Per Pod}

This was determined by carefully counting the number of seed per pod in the five selected plants.

\subsubsection{0 seed Weight}

The weight of 100 seeds was measured using seed counter and an electronic weighting balance and the result was recorded based on treatment basis.

\subsection{Data Analysis}

The data collected was subjected to analysis of variance (ANOVA) to test for significant difference among the means as described by Snedecor and Cochran (1994). The means were compared using Duncan Multiple Range Test (DMRT) (Duncan, 1955).

\subsection{Estimation of Genetic Parameters}

In order to assess and quantify the genotypic variability among the genotypes for thecharacters under study, the following parameters were estimated as given below.

\section{- $\quad$ Estimation of variance components}

Phenotypic and genotypic variances were estimated using following formula, 
Genotypic variances $\left(\mathrm{sg}^{2}\right)=\underline{\text { MSS (genotypes) - MSS (error) }}$

Number of replications ( $\mathrm{r}$ )

Phenotypic variance $\left(\mathrm{sp}^{2}\right)=$ Genotypic variances $\left(\mathrm{sg}^{2}\right)+$ MSS error

Coefficient of variability

Both genotypic and phenotypic coefficients of variability were computed as per themethod suggested by Burton and Devane (1953).

Genotypic coefficient of variability = (Genotypic standard deviation / Gm)*100

Phenotypic coefficient of variability $(\mathrm{PCV})=($ Phenotypic standard deviation $/ \mathrm{Gm}) * 100$

Where,

$\mathrm{Gm}=$ General mean of the character

GCV and PCV values were categorized as low, moderate and high as indicated bySiva Subramanian and Menon (1973). It is as follows,

$$
\begin{aligned}
& 0-10 \%: \text { Low } \\
& 10-20 \%: \text { Moderate }
\end{aligned}
$$

$20 \%$ and above:High

Heritability $\left(\mathrm{h}^{2}\right)$

Heritability in broad sense was computed as the ratio of genetic variance to the totalphenotypic variance as suggested by Hanson et al. (1956) and expressed as percentage.

Heritability $\left(\mathrm{h}^{2}\right)=$ (Genotypic variance / Phenotypic variance) $* 100$

The heritability percentage was categorized as low, moderate and high as given byRobinson et al. (1949).

\section{Results and Discussion}

\subsection{Results}

\subsubsection{Germination Percentage}

The mean germination percentage was 136.4 and the observed minimum and maximum range was between 20 and 50 . The character showed high genotypic coefficient of variation (24.77\%) and high phenotypic coefficient of variation $(93.76 \%)$ and it showed thehigh heritability percentage $(0.49 \%)$ as presented in Table 2 .

\subsubsection{Days to Branching}

The results showed that, the overall average of days to branching was 13.33 days with the range of 12.00 days to 15.00 days. The lower GCV $(8.77 \%)$ and moderate PCV $(11.70 \%)$ values were recorded while thetrait showed the high heritability (31.54\%).

\subsubsection{Days to Flowering}

The mean for days to flowering was 28.73 days with the range of 27.0 days to31 days. It showed low GCV (2.70\%) and low PCV (4.07\%) value, while the trait showed the moderate heritability value (19.3\%).

\subsubsection{Days to $50 \%$ Pod Setting}

The mean of the character was 27.7 days with the range of 25 days to 31 days. It showed the moderate GCV (16.12\%) and high PCV (27.30\%) values, while the character showed low heritability (12.14\%).

\subsubsection{Number of Seeds Per Pod}

This character showed 9.9 mean values with the range of 13.3 to 6.60 . Seeds per pod showed moderate GCV (13.96\%) value, while it showed the high PCV (20.47\%) and moderate heritability percentage (21.62\%).

\subsubsection{Seed weight}

The range observed for hundred seed weight was $11.85 \mathrm{~g}$ to $16.53 \mathrm{~g}$ with the average of $13.28 \mathrm{~g}$. This trait showed moderate GCV (10.02\%) and moderate PCV (10.92\%) values and alsohigh heritability percentage (71.00\%).

\begin{tabular}{|c|c|c|c|}
\hline S/N Characters & & Mean Sum of Squares & Error \\
\hline 1.Germination percentage & Genotype & Replication & 15126 \\
\hline 2. Days to branching & 18531 & 17787 & 1.067 \\
\hline 3. Days to flowering & $5.167^{*}$ & 0.067 & 0.7667 \\
\hline 4.Days to 50\% pod Setting & $2.5667^{*}$ & 0.2667 & 37.27 \\
\hline 5. Number of Seeds per pod & 97.07 & 37.27 & 2.196 \\
\hline 6. 100 Seed Weight & $5.6437^{* *}$ & 4.553 & 0.3307 \\
\hline
\end{tabular}

Table 1: Analysis of Variance (Anova) for Six Quantitative Characters in Cowpea Genotypes

* Significance at 5\% Probability Level

* Significance at $1 \%$ Probability Level 


\begin{tabular}{|rr|c|c|c|c|}
\hline \multicolumn{2}{|c|}{ S/N Characters } & Mean & GCV (\%) & PCV (\%) & $\mathbf{h}^{\mathbf{2}}(\mathbf{\% )})$ \\
\hline 1. & Germination percentage & 136 & 24.771 & 93.764 & 0.487 \\
\hline 2. & Days to branching & 13.33 & 8.7700 & 11.703 & 31.54 \\
\hline 3. & Days to flowering & 28.73 & 2.696 & 4.069 & 19.27 \\
\hline 5. & Days to 50\% pod Setting & 27.7 & 16.118 & 27.304 & 12.14 \\
\hline 6. & Number of Seeds per pod & 9.9 & 13.956 & 20.465 & 21.62 \\
\hline
\end{tabular}

Table 2: Mean and Variability Parameters for Six Characters in Cowpea Genotypes

\section{Discussion}

Genetic variability is the basic knowledge needed for breeders to improve the crops by adopting appropriate method of selection based on variability that exist in the materials. Inthis regard, it is necessary to partition the total variability into heritable and non-heritable components viz., genotypic coefficient of variation (GCV), phenotypic coefficient of variation (PCV) and further to compute heritability for various traits.One of the ways of assessing the variability is through examining the range of variation. The high range of values indicated the good scope for selection of suitable basic material for breeders for further improvement.

Breeders cannot depend only on the knowledge of variability alone to improve thecrop but variance has to be partitioned into phenotypic and genotypic coefficient of variation, which are more reliable for effective selection. Also absolute variability values of differentcharacters do not reveal which of the characters showing high variability. Therefore, thecomponents of variation such as phenotypic and genotypic coefficients of variability and heritability as percent means were computed in respect toyield and yield component characters.

Both genotypic and phenotypic coefficients of variation observed for all the characters studied showed similar trend. PCV values were higher than theGCV values. The higher GCV and PCV values were obtained for the germinationpercentage, days to $50 \%$ pod setting, number of seeds per plant and hundred seed weight. This indicates the substantial variability existing forthese characters and also indicating greater scope for selection of these characters for betterexpression. While the low GCV and PCV obtained for the characters such as days to flowering and days to branchingwere low to moderate for these traits. The result confirmed the finding of [18] [19] who reported that high GCV and PCV values for pods perplant, hundred seed weight and seed yield per plant.Similar results were reported by [20] [19] whereas [21] recorded higher GCV and PCV for the character. Similar resultswere obtained by [21], [19].

Genotypic coefficient of variation together with heritability estimates would give thebest information on extent of the advance to be expected from selection. The estimates ofheritability have a role to play in determining the effectiveness of selection of characterprovided they are considered in conjunction with the predicted genetic advances. In the present set of material, where diverse germplasm collections were involved, high heritability over the mean were exhibited by most of thecharacters which indicates the genotypes have high variability and the selection can be moreeffective for the traits. Proving this, same results were observed by Sohoo et al. (1971) andrevealed that high heritability ranging between $70.2 \%$ to $94.4 \%$. Hence, this indicates the scope for augmenting the Germplasm collection for wider variability, which forms a source to improve the yield and yield componentcharacters. The highest heritability was recorded by hundred seed weight. High heritability recorded by [22], [23] for this character.

\section{Conclusion}

Profound knowledge on variability of the genetic material would be gained in any ofthe breeding programs. Continuous breeding will be ceiling the further improvement ofyield in any crop through narrow down the variability among genotypes. One of the ways toincrease the variability is introduction of genetically diverse new genotypes. An experimentwas conducted atKano University of Science and Technology Wudil research farm, with theobjectives to assess the quantitative characters of cowpea germplasm.

The results revealed that high significant variability for all the tested traits such as germination percentage. High variation recorded for all the characters except days to flowering and days to branching. All the PCV values were higher than the GCV values for each character and showed similar pattern of changing over the characters. The highest heritability was recorded by hundred seed weight.

\section{Recommendation}

Based on the results obtained above, the following recommendations were made;

- The genotype can be used for effective selection based on phenotypic expression and heritability value of a trait.

- Further research should be conducted on advance genetic study in the genotype.

\section{References}

i. Aremu,C.O Adebayo, M.A, Oyegunle, M and Ariyo,J.02007b.Classification of Genetic Diversity and Choice of Parents for Hybridization in Cowpea Vignaunguiculata (L) walp for humid savanna ecology. Africa journal of biotechnology 6;(20):;2333.

ii. FAO. (2000). The state of food insecurity in the world (SOFI) Rome. Italy: FAO-UN. www.fao. org/FOCUS/E/SOFI00/sofi001-e.htm Accessed on March 12th, 2014. 
iii. Adaji, M. J., Olufala, O. O., \&Aliyu, L. (2007, October). Effect of intra-row spacing and stand density on the growth and yield of cowpea (Vignaunguculata (L.) Walp). In Proceedings of the 41st annual conference of the agricultural Society of Nigeria (ASN) held at the Institute for Agricultural Research, Samaru, Ahmadu Bello University, Zaria between 22nd and 26th October.

iv. O M, A., \&Egho, E. O. (2012). Evaluation of eight varieties of cowpea (Vignaunguiculata (L.) Walp) in Asaba agroecological environment, Delta State, Nigeria.European Journal of Sustainable Development, 1(2), 303-314.

v. Agbogidi, O. M. (2010). Response of six cultivars of cowpea (Vignaunguiculata (L.) Walp.) to spent engine oil. African Journal of Food Science and Technology, 1(6), 139-142.

vi. Islam, S., Carmen, R. C., \& Garner, J. O. (2006). Screening for tolerance of stress temperature during germination of twenty-five cowpea (Vignaunguiculata L. Walp) cultivars. JOURNAL OF FOOD AGRICULTURE AND ENVIRONMENT, 4(2), 191.

vii. Baudoin, J and Mergeai G. (2001). Yam Bean SphenostylisStendcarpa. In; R.H. Raemaekers (ed) Crop Production in Tropical Africa Directorate General for International (DGIC), Brussels, Belgium.Pp.372-37

viii. Asumugha, V. U. (2002, November). Sensory and functional properties of dry vegetable cowpea product (Akara). In Proceedings of the 26th Annual Conference of the Nigerian Institute of Food Science and Technology (NIFST) held at the Federal University of Technology, Owerri, Imo State between 4th and 8th of (pp. 66-67).

ix. Achuba, F. I. (2006). The effect of sublethal concentrations of crude oil on the growth and metabolism of cowpea (Vignaunguiculata) seedlings. Environmentalist, 26(1), 17-20.

x. Singh, B. B., Mohan, D. R. Raj, K. E. Dashiell and L.E. N. Jackai (1997). Advances in Cowpea Research, IITA, Ibadan, Nigeria and Japan International Center for Agricultural Science.(JIRCAS). Tsukuba Ibaraki, Japan. Pp 240-247.

xi. Singh, R. K. and B. D. Chaudhary (1985). Biomedical methods in Quantitative Genetic Analysis.Kalyani Publishers Ludhiana, India.

xii. Muoneke, C. O., Ndukwe, O. O., Umana, P. E., Okpara, D. A., \&Asawalam, D. O. (2012). Productivity of vegetable cowpea (Vignaunguiculata (L.)Walp) and maize (Zea mays L.) intercropping system as influenced by component density in a humid tropical zone of South-eastern Nigeria.International Journal of Agriculture and Rural Development, 15(1), 835-847.

xiii. Muoneke, C. O., Ndukwe, O. O., Umana, P. E., Okpara, D. A., \&Asawalam, D. O. (2012). Productivity of vegetable cowpea (Vignaunguiculata (L.)Walp) and maize (Zea mays L.) intercropping system as influenced by component density in a humid tropical zone of South-eastern Nigeria.International Journal of Agriculture and Rural Development, 15(1), 835-847

xiv. Mukhtar, F. B. and B. B. Singh (2006). Influence of photoperiod and Gibberellic acid (GA3) on the growth and flowering of Cowpea (Vignaunguiculata (L) Walp). Journal of food, Agriculture and Environment Vol. 4(2):201203.

xv. Zhang WJ, Zhang XY. 2007. A forecast analysis on fertilizers consumption worldwide. Environmental Monitoring and Assessment, 133:427-434.

xvi. Olofin, E. A (1987).Some aspects of the physical geography of the Kano region and related human responses.p.1625.

xvii. Singh, B. B. (1992). Improved local type cowpeas for the dry Savanna of northern Nigeria. Paper presented at the in-house Review and Cropping Scheme Meeting of the Institute for Agricultural Research, Ahmadu Bello University Zaria Nigeria, pp. 1-8.

xviii. Rangaiah, S., \& Nehru, S. D. (1998). Genetic variability correlation and path analysis in cowpea.Karnataka Journal of Agricultural Sciences, 11(4), 927-932.

xix. Khan, H., Viswanatha, K. P., \&Sowmya, H. C. (2015). Study of genetic variability parameters in cowpea [Vignaunguiculata (L.) Walp] germplasm lines.The Bioscan, 10(2), 747-750.

xx. Selvi, B., Rangasamy, P., Nadarajan, N., Ramalingam, J., \&Vanniarajan, C. (1994). Genetic variability in cowpea.Annals of Agricultural Research, 15, 248-249.

xxi. Sawant, D. S. (1994). Association and path analysis in cowpea.Ann. Agric. Res, 15(2), 134-139.

xxii. Sharma, T. R. (1999). Genetic variability studies in cowpea. Legume Res, 22(1), 65-66.

xxiii. Sarvamangala, S. C. (2004). Genetic studies on different plant types of cowpea (Vignaunguiculata L.). M. Sc.(Agri.) Thesis, Univ. Agric. Sci., Dharwad. 